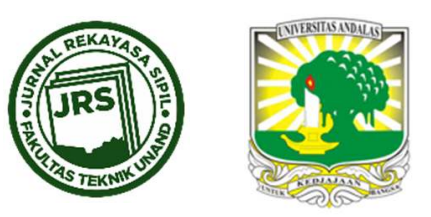

\title{
MANAJEMEN RISIKO PELABUHAN RAKYAT GUNA MENDUKUNG RANTAI PASOK NASIONAL
}

\author{
RAMA ANDRIA ${ }^{1}$, AFRIZAL $^{2}$, AZWAR $^{3}$ \\ ${ }^{1}$ Mahasiswa Magister Ilmu Komunikasi FISIP Universitas Andalas ( $\triangle$ ramaandria1@gmail.com) \\ ${ }^{2}$ Staf Pengajar Jurusan Sosiologi FISIP Universitas Andalas (afrizal_2002au@yahoo.com) \\ ${ }^{3}$ Staf Pengajar Jurusan Sosiologi FISIP Universitas Andalas (nadzelazwar@gmail.com)
}

Naskah diterima : 16 Mei 2018. Disetujui: 25 November 2018. Diterbitkan : 8 Desember 2018

\begin{abstract}
Proyek Peningkatan Kapasitas Jalan Padang Bypass yang dimulai tahun 2014 mendapat resistensi dari warga yang menguasai area yang akan dijadikan objek pelebaran jalan. Penelitian ini bersifat kualitatif melalui wawancara semi terstruktur kepada informan pelaku dan informan pengamat yang bertujuan untuk mendeskripsikan komunikasi Pemerintah Kota Padang dengan warga terdampak, rintangan komunikasi yang dihadapi dan cara mengurangi hambatan komunikasi dalam menangani resistensi tersebut. Dalam upaya penyelesaian masalah, Pemerintah Kota Padang membentuk Tim Penyelesaian Masalah Lahan Pembangunan Jalur II Jalan Padang ByPass. Dalam melaksanakan tugasnya, Tim ini melakukan pendekatan tidak hanya secara formal melalui sosialisasi dan musyawarah, namun juga melalui pendekatan komunikasi antarpribadi berupa kunjungan ke rumah warga dan penyelesaian kasus per kasus. Meskipun proses komunikasi tersebut diganggu oleh persepsi-persepsi negatif berupa kebohongan, kecurigaan, kesimpangsiuran informasi, ketidakpatuhan terhadap konsensus, serta adanya pengaruh dari kelompok kecil dan pemaksaan kehendak, namun secara umum komunikasi antarpribadi yang dilaksanakan oleh Pemerintah Kota Padang dapat mencapai hasil yang baik. Hal ini dapat dilihat dari percepatan menurunnya jumlah lahan yang bermasalah setelah terbentuknya Tim. Namun demikian disadari bahwa penerapan teoriteori komunikasi antarpribadi juga dapat memperlambat proses negosiasi jika tidak dapat dijalankan secara efektif.
\end{abstract}

Kata kunci : Padang-Bypass, pembebasan lahan, komunikasi antarpribadi

\section{PENDAHULUAN}

Pembangunan sebagai proses perubahan dan pembaharuan bagi masyarakat membutuhkan kontribusi komunikasi. Komunikasi digunakan untuk menjembatani arus informasi (ide dan gagasan) pembangunan dari pemerintah kepada masyarakat atau sebaliknya. Melalui proses komunikasi pesan-pesan pembangunan dapat diteruskan dan diterima khalayak untuk tujuan perubahan (Dilla, 2012).

Pengadaan tanah adalah suatu proses penting dalam pelaksanaan pembangunan untuk kepentingan umum. Permasalahan yang sering muncul dalam proses pengadaan tanah 
dapat berupa kesulitan memperoleh tanah itu sendiri, tetapi dapat juga berupa resistensi dari komunitas terdampak (Afrizal, 2006 dan 2007).

Pada tahun 1988, Pemerintah Kota Padang melakukan pembebasan lahan untuk pembangunan jalan Padang-Bypass melalui metode konsolidasi tanah. Dengan metode konsolidasi tanah ini, Pemerintah melakukan penataan kembali penguasaan dan penggunaan lahan yang terkena pembangunan proyek jalan. Ganti rugi hanya terhadap bangunan dan tanaman yang terkena proyek pembangunan. Namun pada saat Pemerintah melanjutkan proyek peningkatan kapasitas jalan Bypass dari dua lajur menjadi empat lajur sepanjang 25,1 kilometer pada tahun 2012, muncul resistensi dari masyarakat terhadap upaya pembebasan lahan tersebut. Masyarakat mulai menyebut bahwa persoalan konsolidasi tanah pada tahun 1990 itu belum tuntas (Tabel 1).

Tabel 1. Persil dan Panjang Tanah Yang Belum Bebas (Tahun 2015)

\begin{tabular}{llrr}
\hline No. & \multicolumn{1}{c}{ Kecamatan } & $\begin{array}{c}\text { Persil Yang Belum } \\
\text { Bebas }\end{array}$ & Panjang (meter) \\
\hline 1. & Koto Tangah & 4 & 400 \\
\hline 2. & Kuranji & 67 & 4500 \\
\hline 3. & Pauh & 11 & 400 \\
\hline 4. & Lubuk Begalung & 8 & 600 \\
\hline Total & & 90 & 5900 \\
\hline
\end{tabular}

Penelitian kualitatif ini dilakukan untuk mendeskripsikan komunikasi Pemerintah Kota Padang dengan warga terdampak pembebasan tanah pada proyek peningkatan kapasitas Jalan Padang-Bypass serta mendeskripsikan hambatan atau rintangan komunikasi yang dihadapi Pemerintah Kota Padang dan cara mengurangi hambatan komunikasi tersebut dalam mengatasi resistensi. Penelitian dilakukan melalui wawancara semi terstruktur kepada informan pelaku dan informan pengamat yang berada di wilayah Kecamatan Kuranji sebagai wilayah yang memiliki persil bermasalah terbanyak.

\section{TEORI KOMUNIKASI}

Kata komunikasi atau dalam bahasa Inggris communication berasal dari kata Latin communis yang berarti sama, communico, communicatio, atau communicare yang berarti membuat sama (to make common) (Mulyana, 2005). Dengan demikian pengertian komunikasi bermaksud agar suatu pikiran, suatu makna, atau suatu pesan dianut secara sama oleh pelakunya.

Komunikasi salah satu syarat bagi berlangsungnya hubungan antarmanusia karena pada dasarnya manusia adalah makhluk sosial yang harus selalu berkomunikasi dengan manusia lainnya. Menurut Harold Lasswell cara yang baik untuk menggambarkan komunikasi adalah dengan menjawab pertanyaan: "who says what in which channel to whom with what effect?” (siapa mengatakan apa dengan saluran apa kepada siapa dengan pengaruh bagaimana?) (Effendy, 2013)

Teori Lasswell ini menunjukkan bahwa komunikasi itu meliputi lima unsur sebagai jawaban dari pertanyaan yang diajukan, yakni: Komunikator (communicator, source, sender), Pesan (message), Komunikan (communicant, communicate, receiver), Media (channeI), dan Efek (effect, influence). 
Dengan demikian secara sederhana dapat disimpulkan bahwa komunikasi adalah proses penyampaian pikiran, perasaan dan pertukaran informasi dari seseorang kepada seseorang lainnya yang dimaksudkan untuk menyamakan persepsi tentang sesuatu hal.

Dalam komunikasi seringkali terdapat hambatan dalam penyampaian pesan, sehingga pesan yang sampai ke komunikan tidak tepat sesuai dengan yang dimaksudkan oleh komunikator. Empat jenis hambatan dalam berkomunikasi, yaitu gangguan yang disebabkan oleh kerusakan saluran kesalahan bahasa, kepentingan, motivasi terpendam dan prasangka (Effendy, 2013). Sedangkan Cangara berpendapat bahwa gangguan komunikasi (noise) dapat disebabkan oleh gangguan teknis, semantik dan psikologis, rintangan fisik, rintangan status, rintangan kerangka berpikir maupun rintangan budaya (Cangara, 2016)

\section{PERMASALAHAN}

\subsection{Kronologis Pembangunan Jalan Padang ByPass}

Peraturan Pemerintah Republik Indonesia Nomor 17 tahun 1980 tentang Perubahan Batas Wilayah Kotamadya Tk II Padang memperluas Kota Padang dengan memasukkan sebagian wilayah Kota Pariaman ke dalam wilayah Kota Padang. Adanya pemekaran Kota Padang tersebut menuntut sarana dan prasarana penunjang pengembangan wilayah perkotaan. Karena itu, dokumen masterplan Kota Padang Tahun 1983-2003 memuat rencana pembangunan Jalan Padang-Bypass yang melintasi kawasan perluasan wilayah kota tersebut.

Pada tahun 1988, Pemerintah Kota Padang menetapkan bahwa pembebasan tanah dilakukan melalui mekanisme konsolidasi tanah. Dengan pola ini maka tiap-tiap pemilik tanah dalam jarak 100 meter ke kiri dan 100 meter ke kanan as jalan harus memberikan $30 \%$ tanahnya. Tanah yang 30\% tersebut selanjutnya selain digunakan untuk jalan Bypass, juga dimanfaatkan untuk jalan masuk dan untuk ganti rugi bagi pemilik tanah lainnya. (Gambar 1)

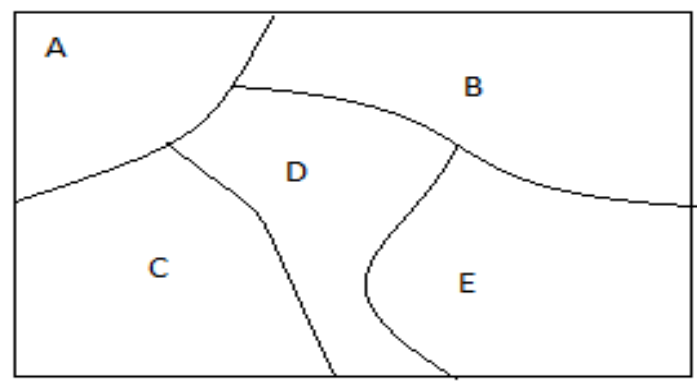

Sebelum Konsolidasi

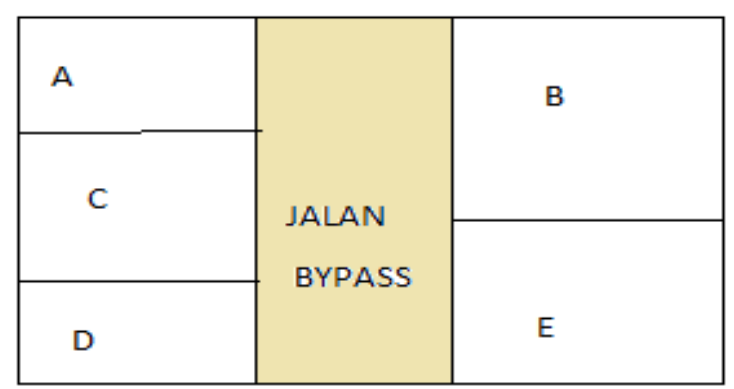

Setelah Konsolidasi

Gambar 1. Konsolidasi Tanah Padang-Bypass (Colombijn, 2006)

Pada tahap selanjutnya diberikan ganti rugi tanaman dan bangunan pada jalur badan jalan 40 meter melalui tabungan Bank Rakyat Indonesia (BRI) atas nama pemilik tanah. Setelah itu pembangunan jalan Padang-ByPass dilaksanakan dari Simpang Lubuk Begalung sampai ke Batas Kota Padang dari tahun 1990 sampai dengan tahun 1993.

Meskipun secara umum masyarakat telah menyetujui mekanisme pembebasan lahan yang dilaksanakan oleh Pemerintah Kota Padang saat itu, namun dalam prakteknya tetap muncul 
ketidakpuasan-ketidakpuasan. Hal ini ditunjukkan antara lain dengan memindahkan tiang penanda batas rencana jalan, mempertanyakan nilai ganti rugi yang diterima, sampai berusaha mempengaruhi pejabat kota untuk memperkecil luas lahan yang harus mereka serahkan (Colombijn, 2006). Hal seperti ini tidak banyak terekspos mengingat kebijakan politik Orde Baru pada saat itu yang mengontrol media secara ketat.

Pada tahun 2014, menyikapi perkembangan lalu-lintas yang terjadi di kota Padang, Balai Besar Pelaksana Jalan Nasional II Kementerian Pekerjaan Umum menyediakan anggaran untuk Peningkatan Kapasitas Jalan Padang-ByPass dari 2 lajur menjadi 4 lajur (2 arah) dengan pinjaman dana dari Korea Selatan (EDCF Loan No. INA 17). Masa penyelesaian pekerjaan diperkirakan berlangsung dari tanggal 8 Agustus 2014 sampai dengan 7 Agustus 2016 (730 hari kalender) dengan total anggaran sebesar Rp. 358.291.208.000,- (diluar pajak).

Rencana pembangunan ini memiliki panjang 26,5 kilometer dengan lokasi dari Simpang Gaung Teluk Bayur sampai dengan Duku Fly Over (Kabupaten Padang Pariaman) dimana 25,1 kilometer diantaranya berada pada wilayah Kota Padang.

\subsection{Permasalahan Pembebasan Lahan Jalan Padang By-Pass}

Pada tahun 2014, menyikapi perkembangan lalu-lintas yang terjadi di kota Padang, Balai Besar Pelaksana Jalan Nasional II Kementerian Pekerjaan Umum menyediakan anggaran untuk Peningkatan Kapasitas Jalan Padang-ByPass dari 2 lajur menjadi 4 lajur (2 arah) dengan pinjaman dana dari Korea Selatan (EDCF Loan No. INA 17) dengan masa penyelesaian pekerjaan diperkirakan berlangsung dari tanggal 8 Agustus 2014 sampai dengan 7 Agustus 2016 (730 hari kalender) dan total anggaran sebesar Rp. 358.291.208.000,- (diluar pajak). Rencana pembangunan ini memiliki panjang 26,5 kilometer dengan lokasi dari Simpang Gaung Teluk Bayur sampai dengan Duku Fly Over (Kabupaten Padang Pariaman), dimana 25,1 kilometer diantaranya berada pada wilayah Kota Padang.

Pada saat pelaksanaan Proyek Peningkatan Kapasitas Jalan Padang-ByPass ini dilaksanakan muncul beberapa permasalahan pembebasan lahan, khususnya yang berkaitan dengan proses konsolidasi pada pembangunan jalan Padang-Bypass awal pada tahun 1989/1990 lalu. Permasalahan tersebut adalah: (Pemko Padang, 2015)

1. Konsolidasi belum selesai dan belum tuntas sebanyak 84 peserta konsolidasi, dimana didalamnya terdapat 16 peserta dalam proses perkara di Pengadilan.

Faktor penyebabnya antara lain adalah:

a. Sertifikat Hak Milik belum terbit karena masalah internal kaum, keberatan dalam memenuhi persyaratan, lokasi pengembalian tanah hasil konsolidasi tidak jelas, lokasi pengembalian tanah hasil konsolidasi dikuasai pemilik asal (baik berupa tanah kosong atau ada bangunan), menolak lokasi tanah hasil konsolidasi dan menolak metode konsolidasi.

b. Pengembalian tanah hasil konsolidasi belum tuntas karena sebagian sertifikat konsolidasi belum diproses oleh BPN dan sebagian lagi ada yang menolak sistem konsolidasi.

c. Lokasi tanah hasil konsolidasi tidak bisa dikuasai (sebagian/seluruhnya) meskipun Sertifikat Hak Milik sudah terbit karena dihalangi oleh pemilik tanah asal.

d. Kelebihan luas tanah konsolidasi.

e. Kekurangan luas tanah konsolidasi. 
2. Dalam jalur 40 meter terdapat 212 unit bangunan masyarakat pemilik tanah asal/peserta konsolidasi yang belum selesai prosesnya.

3. Adanya bangunan liar/tanpa IMB dan berdiri pada jalur 40 meter yang telah dibayar ganti rugi bangunan dan tanamannya.

Dengan adanya permasalah tersebut, jika diakumulasikan maka panjang jalan yang belum dapat dikerjakan sepanjang 4,5 Km (per September 2015). Hal ini tentu akan berimbas kepada target penyelesaian pekerjaan pada Agustus 2016.

\section{METODOLOGI PENELITIAN}

Informan penelitian adalah orang yang memberikan informasi baik tentang dirinya ataupun orang lain atau suatu kejadian dan suatu hal kepada peneliti atau pewawancara. Lebih lanjut Afrizal membagi kategori informan menjadi informan pengamat dan informan pelaku. Informan pengamat adalah informan yang memberikan informasi tentang orang lain atau suatu kejadian kepada peneliti. Sedangkan informan pelaku adalah informan yang memberikan keterangan tentang dirinya, perbuatannya, pikirannya, interpretasinya (maknanya) atau pengetahuannya (Afrizal, 2014).

Informan dalam penelitian ini ditentukan dengan menggunakan mekanisme penentuan informan dengan disengaja (purposive). Sebelum melakukan penelitian peneliti menetapkan kriteria tertentu yang harus dipenuhi oleh orang yang akan dijadikan sumber informasi/informan. Dalam hal ini peneliti memilih informan yang terlibat dan memahami tentang pembebasan tanah pada proyek peningkatan kapasitas jalan Padang-Bypass (Tabel 2).

Tabel 2. Daftar Informan

\begin{tabular}{|c|c|c|}
\hline Informan & Nama (inisial) & Status/Jabatan \\
\hline 1. & MM & Kepala Seksi Tata Pemerintahan Kec. Kuranji \\
\hline 2. & $\mathrm{AA}$ & Mantan Kepala Seksi Tata Pemerintahan Kec. Kuranji \\
\hline 3. & SS & Tokoh masyarakat Kecamatan Kuranji \\
\hline 4. & ARM & Pemilik tanah, Kaum Caniago \\
\hline 5. & BB & Pemilik tanah, Mamak Kaum Koto \\
\hline 6. & SU & $\begin{array}{l}\text { Kepala Seksi Basis Data Dinas Pekerjaan Umum dan } \\
\text { Penataan Ruang Kota Padang }\end{array}$ \\
\hline 7. & SY & $\begin{array}{l}\text { Fungsional Umum Dinas Perumahan Rakyat, Kawasan } \\
\text { Permukiman dan Pertanahan Kota Padang }\end{array}$ \\
\hline 8. & SL & Mantan Camat Kuranji \\
\hline 9. & $\mathrm{AD}$ & $\begin{array}{l}\text { Pejabat Pembuat Komitmen Proyek Peningkatan Kapasitas } \\
\text { Padang-Bypass }\end{array}$ \\
\hline 10. & YU & $\begin{array}{l}\text { Pejabat Pelaksana Teknis Kegiatan Pembebasan Lahan Dinas } \\
\text { Pekerjaan Umum dan Penataan Ruang Provinsi Sumatera } \\
\text { Barat }\end{array}$ \\
\hline 11. & SD & Pemilik tanah, Kaum Tanjung \\
\hline
\end{tabular}

\section{PEMBAHASAN DAN HASIL}

\subsection{Resistensi Masyarakat}

Resistensi dari masyarakat muncul karena masyarakat tidak menginginkan kelanjutan dari pola proses pembebasan lahan yang masih menggunakan mekanisme konsolidasi tanah. Masyarakat pada saat ini lebih cenderung kepada mekanisme pembayaran ganti rugi tanah. 
Namun aturan mekanisme pembebasan lahan yang dipakai, yaitu berdasarkan Undangundang Nomor 2 Tahun 2012 tentang Pengadaan Tanah Bagi Pembangunan Untuk Kepentingan Umum, tidak memungkinkan untuk itu. Akibatnya sebagian pemilik lahan melakukan resistensi dengan bersifat pasif bahkan apatis terhadap pembebasan lahan Padang-Bypass. Mereka juga tidak berusaha untuk membuka ruang dialog dengan Pemerintah Kota Padang.

Sebagian lagi menunjukkan resistensinya secara aktif dengan cara tidak mengizinkan alat berat bekerja pada lokasi yang diklaim sebagai lahan mereka. Hal ini tentu mengganggu jadwal penyelesaian pekerjaan konstruksi fisik.

Tabel 2 memperlihatkan perkembangan jumlah persil yang masih bermasalah per kecamatan di sepanjang jalur proyek peningkatan kapasitas jalan Padang Bypass. Dari tabel terlihat bahwa dari Februari sampai dengan September 2015 pencapaian hasil pembebasan lahan tidak signifikan, bahkan cenderung fluktuatif. Hal ini menunjukkan adanya permasalahan dalam pembebasan lahan di lapangan.

Tabel 3. Jumlah Persil Padang-Bypass yang Bermasalah (Tahun 2012 - 2015)

\begin{tabular}{|c|c|c|c|c|c|c|}
\hline \multirow{3}{*}{ No. } & \multirow{3}{*}{ Kecamatan } & \multicolumn{5}{|c|}{ Persil Yang Belum Bebas } \\
\hline & & \multicolumn{2}{|c|}{ Des 2012} & \multirow[t]{2}{*}{ Feb 2015} & \multirow[t]{2}{*}{$\begin{array}{l}\text { Maret } \\
2015 \\
\end{array}$} & \multirow[t]{2}{*}{$\begin{array}{l}\text { Sept } \\
2015 \\
\end{array}$} \\
\hline & & $\begin{array}{c}\text { Bangunan } \\
\text { Liar }\end{array}$ & Rumah & & & \\
\hline 1. & Koto Tangah & 25 & - & 5 & 10 & 4 \\
\hline 2. & Kuranji & 240 & - & 76 & 67 & 67 \\
\hline 3. & Pauh & 13 & - & 10 & 2 & 11 \\
\hline 4. & Lubuk Begalung & 21 & 24 & 13 & 4 & 8 \\
\hline
\end{tabular}

\subsection{Komunikasi Pemerintah Kota Padang dengan Pemilik Lahan}

Sebagaimana telah disinggung sebelumnya bahwa pesan utama Pemerintah Kota Padang yang ditolak oleh masyarakat pemilik lahan bukanlah proyek Peningkatan Kapasitas Jalan Padang Bypass itu sendiri, namun adalah pembebasan lahan proyek yang tetap menggunakan mekanisme konsolidasi. Masyarakat merasa bahwa pembebasan lahan Padang-Bypass dengan mekanisme yang sama 22 tahun yang lalu masih menyisakan persoalan yang belum diselesaikan oleh pihak Pemerintah Kota Padang hingga saat ini. Akibatnya masyarakat menolak pesan untuk mengosongkan lahan yang mereka tempati meskipun menurut pihak Pemerintah Kota Padang lahan tersebut sudah dibebaskan 22 tahun yang lalu. Pesan yang ingin mereka sampaikan adalah agar persoalan yang tersisa diselesaikan terlebih dahulu sebelum berbicara soal kelanjutan pembebasan lahan lainnya.

Perbedaan persepsi juga menimbulkan rintangan kerangka berpikir antara Pemerintah Kota Padang dengan pemilik lahan. Pemerintah Kota beranggapan bahwa proyek peningkatan kapasitas jalan Padang Bypass akan menguntungkan warga dalam hal peningkatan harga tanah, sementara pemilik lahan beranggapan bahwa mereka akan dirugikan karena kehilangan hak atas kepemilikan sebagian tanah mereka yang bernilai strategis tanpa adanya ganti rugi tanah.

Dalam kasus ini terlihat bahwa gangguan komunikasi (noise) yang terjadi adalah gangguan psikologis. Gangguan psikologis ini meliputi semua jenis gangguan yang bersumber dari faktor-faktor psikologis seperti kepedulian (awareness), persepsi, motivasi serta hambatan mental lain yang menganggu proses komunikasi (Suryanto, 2015). 
Pemerintah Kota Padang mencoba menyelesaikan persoalan pembebasan lahan ini dengan membentuk Tim Penyelesaian Masalah Lahan Pembangunan Jalur II Jalan Padang-ByPass melalui Surat Keputusan Walikota Padang Nomor 115 tanggal 22 Maret 2016.

Dalam menjalankan tugasnya, media utama yang digunakan dalam proses komunikasi pembebasan lahan Padang-Bypass adalah tatap muka secara langsung antara komunikator dan komunikan. Tatap muka ini dilangsungkan baik dalam bentuk rapat dan pertemuan resmi di kantor-kantor pemerintah atau tempat lain yang disepakati maupun pertemuan non formal, baik di lokasi proyek maupun di rumah-rumah warga. Didalam pertemuan tatap muka ini biasanya didukung oleh media komunikasi lain seperti bahan bacaan, bahan tayang, dokumen-dokumen pendukung, serta contoh-contoh dokumen yang dibutuhkan.

Selain tatap muka secara langsung, media yang digunakan oleh kedua belah pihak dalam berkomunikasi adalah papan pengumuman, surat edaran, plang larangan serta garis pembatas (police line).

Secara umum proses komunikasi Pemerintah Kota Padang yang terjadi dalam pembebasan lahan Padang-Bypass dapat digambarkan dalam tabel 4.

Tabel 4. Proses Komunikasi Pemko Padang dalam Kegiatan Pembebasan Lahan Padang

\begin{tabular}{|c|c|c|c|c|}
\hline \multicolumn{5}{|c|}{ Bypass } \\
\hline No. & Pesan & Komunikator & Komunikan & Media \\
\hline 1. & $\begin{array}{l}\text { Peraturan terkait } \\
\text { pertanahan }\end{array}$ & Pemko Padang & $\begin{array}{l}\text { Masyarakat } \\
\text { terdampak }\end{array}$ & $\begin{array}{l}\text { Tatap muka, dokumen } \\
\text { per-UU-an, peraturan } \\
\text { lainnya, bahan tayang }\end{array}$ \\
\hline 2. & $\begin{array}{l}\text { Pentingnya kegiatan } \\
\text { pelebaran jalan Padang } \\
\text { ByPass dan manfaat } \\
\text { ekonomi }\end{array}$ & Pemko Padang & $\begin{array}{l}\text { Masyarakat } \\
\text { terdampak }\end{array}$ & $\begin{array}{l}\text { Tatap muka, bahan } \\
\text { tayang }\end{array}$ \\
\hline 3. & $\begin{array}{l}\text { Inventarisasi permasalahan } \\
\text { konsolidasi lahan dan } \\
\text { alternatif solusi }\end{array}$ & Pemko Padang & $\begin{array}{l}\text { Masyarakat } \\
\text { terdampak }\end{array}$ & Tatap muka \\
\hline 4. & $\begin{array}{l}\text { Perkembangan } \\
\text { penyelesaian permasalahan } \\
\text { pembebasan lahan Padang } \\
\text { Bypass }\end{array}$ & Pemko Padang & $\begin{array}{l}\text { Pemerintah } \\
\text { Pusat }\end{array}$ & Tatap muka \\
\hline 5. & $\begin{array}{l}\text { Permintaan dokumen } \\
\text { kepemilikan aset }\end{array}$ & Pemko Padang & $\begin{array}{l}\text { Masyarakat } \\
\text { terdampak }\end{array}$ & $\begin{array}{l}\text { Tatap muka, contoh } \\
\text { dokumen }\end{array}$ \\
\hline 6. & $\begin{array}{l}\text { Larangan memasuki lahan } \\
\text { yang bermasalah }\end{array}$ & $\begin{array}{l}\text { Masyarakat } \\
\text { pemilik lahan } \\
\text { (dokumentasi } \\
\text { foto) }\end{array}$ & $\begin{array}{l}\text { Kontraktor } \\
\text { pelaksana } \\
\text { pekerjaaan }\end{array}$ & $\begin{array}{l}\text { Tatap muka, plang } \\
\text { larangan }\end{array}$ \\
\hline 7. & $\begin{array}{l}\text { Saran untuk membuat } \\
\text { Surat Pernyataan } \\
\text { Keberatan }\end{array}$ & $\begin{array}{l}\text { PPK dan } \\
\text { kontraktor } \\
\text { pelaksana } \\
\text { pekerjaan } \\
\end{array}$ & $\begin{array}{l}\text { Masyarakat } \\
\text { pemilik } \\
\text { lahan }\end{array}$ & $\begin{array}{l}\text { Tatap muka, contoh } \\
\text { surat pernyataan }\end{array}$ \\
\hline 8. & $\begin{array}{l}\text { Pengosongan lahan yang } \\
\text { sudah dibebaskan secara } \\
\text { sukarela }\end{array}$ & Pemko Padang & Masyarakat & $\begin{array}{l}\text { Tatap muka, } \\
\text { pengumuman, seruan }\end{array}$ \\
\hline 9. & $\begin{array}{l}\text { Argumentasi keberatan } \\
\text { untuk dibebaskan dan } \\
\text { tuntutan ganti rugi }\end{array}$ & $\begin{array}{l}\text { Masyarakat dan } \\
\text { penasehat hukum } \\
\text { masyarakat }\end{array}$ & $\begin{array}{l}\text { Pemko } \\
\text { Padang }\end{array}$ & $\begin{array}{l}\text { Tatap muka, spanduk, } \\
\text { plang larangan }\end{array}$ \\
\hline
\end{tabular}




\begin{tabular}{lllll}
\hline No. & \multicolumn{1}{c}{ Pesan } & Komunikator & Komunikan & \multicolumn{1}{c}{ Media } \\
\hline 10. & Pengosongan lokasi secara & Pemko Padang & Masyarakat & Tatap muka, seruan \\
& $\begin{array}{l}\text { paksa untuk lahan yang } \\
\text { dianggap sudah selesai } \\
\text { permasalahannnya }\end{array}$ & $\begin{array}{l}\text { dan aparat } \\
\text { penegak hukum }\end{array}$ & & \\
\hline
\end{tabular}

Teori menyatakan bahwa kegagalan komunikasi seringkali disebabkan oleh ketidakcermatan dalam mempersepsikan pihak lain. Sedangkan persepsi itu sendiri dibentuk oleh unsur-unsur pengamat, objek dan konteks atau situasi yang dihadapi (Tubbs dan Moss, 2012).

Adapun penyebab persepsi negatif yang muncul antara pemilik lahan dan Pemerintah Kota Padang dalam pembebasan jalur Padang Bypass sebagai akibat konteks hubungan pada masa lalu. Hal itu antara lain adalah:

a. Kebohongan

Kebohongan (deception) terjadi apabila para komunikator mengendalikan informasi berisikan pesan-pesan dengan makna yang menyimpang dari kebenaran sebagaimana yang mereka ketahui (Budyatna \& Ganiem, 2011). Dalam kasus ini beberapa warga menyoroti janji-janji masa lalu yang tidak ditepati oleh Pemerintah Kota Padang misalnya soal lokasi tanah pengganti konsolidasi maupun penggratisan biaya pengurusan Izin Mendirikan Bangunan dan biayabiaya lainnya.

b. Kecurigaan

Kecurigaan muncul setelah salah satu pihak mempersepsikan bahwa pihak lain berucap atau bertindak tidak jujur, tanpa bukti yang cukup untuk menganggapnya bermuka dua (Budyatna \& Ganiem, 2011). Dalam hal ini beberapa warga curiga tentang adanya oknum pejabat dan orang dekatnya yang diduga memanfaatkan posisinya untuk kepentingan pribadi di kawasan PadangByPass.

c. Kesimpangsiuran informasi

Akibat persepsi yang sudah terbentuk maka para pelaku komunikasi tidak mampu lagi menyaring kebenaran informasi yang beredar. Dalam kondisi ini semua informasi bisa dianggap benar atau salah sepanjang bersinggungan dengan kepentingan mereka.

d. Ketidakpatuhan terhadap konsensus

Beberapa warga menyampaikan tentang adanya warga yang dengan sengaja menolak untuk mengikuti aturan konsolidasi yang telah disepakati dengan berbagai alasan.

e. Pengaruh kelompok kecil

Kelompok kecil yang berada diantara komunikator dan komunikan dapat menjadi penyebab terdistorsinya informasi dan terganggunya proses komunikasi. Dalam kasus ini peran pengacara yang mendampingi warga maupun peranan internal kaum disinyalir sebagai salah satu penyebab gangguan komunikasi antara Pemerintah Kota Padang sebagai komunikator dan pemilik lahan sebagai komunikan.

f. Pemaksaan kehendak

Pemaksaan kehendak oleh salah satu pihak membuat terganggunya proses komunikasi sekaligus membenarkan persepsi negatif yang telah muncul sebelumnya. 


\subsection{Hasil Komunikasi}

Sejak dibentuknya Tim Penyelesaian Masalah Lahan Pembangunan Jalur II Jalan PadangByPass melalui Surat Keputusan Walikota Padang Nomor 115 tanggal 22 Maret 2016, terlihat bahwa proses pembebasan lahan untuk proyek Peningkatan Kapasitas Jalan Padang-ByPass mengalami percepatan yang cukup signifikan.

Hal ini dapat dilihat dari data sebelum dan setelah pembentukan Tim, khusus untuk Kecamatan Kuranji sebagai wilayah penelitian. Persil bermasalah yang semula stagnan sepanjang tahun 2015 dengan cepat berkurang dari 67 persil menjadi 17 persil pada awal 2017 atau mengalami penurunan sebesar 74,6\% (Tabel 5).

Tabel 5. Kemajuan Pembebasan Lahan Padang-ByPass di Kecamatan Kuranji

\begin{tabular}{lllllll}
\hline Kecamatan & \multicolumn{2}{l}{ Persil Yang Belum Bebas } & & & \\
& \multirow{2}{*}{ Des 2012 } & & $\begin{array}{l}\text { Feb } \\
\text { 2015 }\end{array}$ & $\begin{array}{l}\text { Maret } \\
2015\end{array}$ & Sept 2015 & $\begin{array}{l}\text { Jan } \\
2017\end{array}$ \\
\hline Kuranji & Bangunan Liar & Rumah & & & & \\
\hline & 240 & - & 76 & 67 & 67 & 17 \\
\hline
\end{tabular}

Penurunan jumlah persil lahan yang bermasalah ini tentu tidak bisa dilepaskan dari peranan komunikasi yang dilakukan oleh Tim dalam meyakinkan masyarakat untuk mencari solusi permasalahan terbaik. Keberhasilan per kategori masalah ini dapat dilihat pada Tabel 6 .

Tabel 6. Kemajuan Pembebasan Tanah Bypass di Kecamatan Kuranji per Kategori Masalah

\begin{tabular}{llcc}
\hline \multirow{2}{*}{ No } & \multicolumn{1}{c}{ Permasalahan Pembebasan Lahan } & \multicolumn{2}{c}{ Jumlah Persil } \\
\cline { 2 - 4 } 1. & $\begin{array}{l}\text { Tanah pengembalian hasil konsolidasi belum bisa } \\
\text { dikuasai }\end{array}$ & 11 & 6 \\
\hline 2. & Sertifikat pagang-gadai bermasalah & 1 & 1 \\
\hline 3. & Proses pengadilan gugatan kepada Pemko Padang & 13 & 4 \\
\hline 4. & Kekurangan pengembalian tanah hasil konsolidasi & 14 & - \\
\hline 5 & $\begin{array}{l}\text { Proses alas hak/sertifikat hasil konsolidasi belum } \\
\text { selesai }\end{array}$ & 12 & 3 \\
\hline 6. & Kaum belum sepakat soal pembuatan alas hak & 2 & 2 \\
\hline 7. & $\begin{array}{l}\text { Penempatan lokasi tanah pengganti hasil konsolidasi } \\
\text { bermasalah }\end{array}$ & 1 & - \\
\hline 8. & $\begin{array}{l}\text { Meminta ganti rugi untuk tanah yang telah } \\
\text { dikonsolidasi }\end{array}$ & 1 & - \\
\hline 9. & $\begin{array}{l}\text { Lokasi tanah pengganti hasil konsolidasi sesuai } \\
\text { dengan sertifikat yang diterbitkan tidak jelas }\end{array}$ & 4 & - \\
\hline 10. & Pemilik belum bisa ditemui & 6 & - \\
\hline 11. & Pemilik tidak menerima sistem konsolidasi & 1 & 1 \\
\hline 12. & $\begin{array}{l}\text { Meminta biaya pemindahan bangunan kelokasi tanah } \\
\text { hasil konsolidasi }\end{array}$ & 1 & - \\
\hline Total & & 67 & 17 \\
\hline
\end{tabular}

Proses komunikasi yang berlangsung relatif baik, terlihat dari banyaknya persil tanah yang bisa dibebaskan. Pada fase ini, dinamika komunikasi bisa dikatakan ideal, berada di garis tengah. Para pihak bisa memposisikan dirinya sehingga kesepakatan bisa tercapai. 


\subsection{Peranan Komunikasi Antarpribadi dalam Pembebasan Lahan Padang Bypass}

Komunikasi antarpribadi merupakan proses komunikasi yang berlangsung antara dua orang atau lebih secara tatap muka (Cangara, 2016). Adapun ciri-cirinya adalah (Nurudin, 2016):

a. Komunikasi dilakukan secara tatap muka.

b. Pembicaraan berlangsung sepotong-sepotong.

c. Kedudukan setara dan tidak ada dominasi pembicaraan.

d. Sumber dengan penerima sulit dibedakan. Keduanya bertindak selaku komunikator sekaligus komunikan.

Hasil wawancara dengan para informan pada penelitian ini memperlihatkan bahwa peranan komunikasi antarpribadi menjadi salah satu penentu keberhasilan aparat Pemerintah Kota Padang dalam melakukan pendekatan kepada masyarakat untuk menyelesaikan masalah pembebasan lahan Padang-Bypass. Komunikasi yang dibangun bersifat non formal dan lebih pribadi. Misalnya dengan mendatangi rumah dan tempat berkumpulnya warga pada malam hari.

Dalam pelaksanaannya, aparat Pemerintah Kota Padang melakukannya melalui pendekatan komunikasi persuasif. Komunikasi persuasif adalah komunikasi yang bertujuan untuk mengubah kepercayaan, sikap, pendapat dan perilaku orang lain, baik secara verbal maupun non verbal sehingga orang tersebut bertindak sesuai dengan yang diharapkan oleh komunikator (Suryanto, 2015).

Hasil wawancara juga memperlihatkan beberapa teori komunikasi antarpribadi yang dipraktekkan oleh aparat Pemerintah Kota Padang dalam melakukan pendekatan persuasif tersebut adalah:

\section{a. Teori Akomodasi Komunikasi}

Teori akomodasi komunikasi berkaitan dengan bagaimana seseorang akan menyesuaikan gaya komunikasinya baik verbal maupun non verbal dengan lawan bicaranya. Hal ini dilakukan dalam rangka mengurangi perbedaan-perbedaan dan meningkatkan kesamaankesamaan antarpribadi (Budyatna, 2015).

Penggunaan kata-kata "memberi jaminan", "mengakomodir", atau "kepentingan kita bersama" sebagaimana disampaikan oleh para informan menunjukkan bahwa aparat Pemerintah Kota Padang dalam melakukan komunikasi berusaha untuk menggunakan bahasa yang dapat ditangkap dan dipersepsikan positif oleh lawan bicaranya. Dengan demikian pemilihan kata yang sesuai akan sangat mempengaruhi keberhasilan upaya persuasi yang dilakukan. Penggunaan bahasa yang tepat akan menunjang keberhasilan sebuah proses komunikasi.

Namun demikian pada titik tertentu teori akomodasi komunikasi ini akan dapat menghilangkan penghargaan kepada partner berkomunikasi meskipun ia adalah seseorang atau sekelompok orang yang memiliki strata sosial lebih tinggi. Misalnya antara masyarakat dan pejabat pemerintahan. Bahkan karena telah merasa setara, salah satu pihak akan dengan mudah mengeluarkan ucapan atau tindakan yang merendahkan pihak lain, misalnya memaki atau melakukan ancaman.

b. Teori Pertukaran Sosial 
Dalam teori pertukaran sosial, keputusan-keputusan didasarkan pada proyeksi-proyeksi terhadap imbalan-imbalan dan biaya-biaya mengenai tindakan tertentu (Budyatna, 2015).

Dalam kasus pembebasan lahan jalan Padang-ByPass, pemilik lahan berusaha mempertahankan tanahnya karena nilai ekonomi tanah tersebut pada saat ini sangat tinggi. Kisruhnya persoalan konsolidasi tanah di masa lalu membuat mereka memiliki kesempatan untuk melakukan kalkulasi ulang antara biaya yang telah atau akan mereka keluarkan dengan imbalan yang mereka kehendaki.

Perhitungan imbalan dan biaya juga yang menyebabkan beberapa pemilik lahan bersedia bernegosiasi dan menerima imbalan "dibawah tangan" dari kontraktor dengan konsekuensi mengizinkan kontraktor bekerja di tanahnya sebagaimana diungkap beberapa informan. Perhitungan imbalan dan biaya juga yang membuat negosiasi internal kaum menjadi sulit, membuat pemilik lahan merasa tanah hasil konsolidasinya bernilai lebih rendah dari tanah aslinya atau membuat pemilik lahan tidak mau mematuhi konsensus untuk memberikan $30 \%$ lahannya.

Jika imbalan dan biaya dalam pertukaran sosial sudah dihitung oleh masing-masing pihak, maka komunikasi berfungsi menjadi alat negosiasi. Pertukaran sosial akan berjalan jika masing-masing pihak merasa memperoleh imbalan yang melebihi biaya yang dikeluarkannya.

Dalam prakteknya, penggunaan teori pertukaran sosial yang berdasarkan perhitungan untung-rugi salah satu pihak semata akan menghambat dan memperlama sebuah proses komunikasi untuk pencapaian konsensus. Praktek pertukaran sosial yang diharapkan adalah yang mengedepankan perhitungan berdasarkan keuntungan dan kepentingan bersama.

\section{PENUTUP}

\subsection{Kesimpulan}

Dalam proses komunikasi pada pembebasan lahan Padang-Bypass terjadi gangguan komunikasi psikologis yaitu persepsi negatif akibat sejarah pembebasan lahan di lokasi yang sama di masa lalu. Persepsi negatif tersebut meliputi kebohongan, kecurigaan, kesimpangsiuran informasi, ketidakpatuhan terhadap konsensus, adanya pengaruh dari kelompok kecil dan pemaksaan kehendak.

Hasil penelitian menunjukkan bahwa bentuk komunikasi antarpribadi yang diterapkan Pemerintah Kota Padang dalam berhubungan dengan masyarakat membawa hasil yang lebih efektif jika dibandingkan dengan pendekatan sebelumnya yang bersifat formal. Hal ini dapat dilihat dari percepatan penurunan lahan bermasalah setelah Pemko Padang membuka jalur komunikasi yang bersifat antarpribadi kepada masyarakat.

Dari penelitian juga terlihat bahwa penerapan Teori Akomodasi Komunikasi dan Teori Pertukaran Sosial oleh aparat Pemerintah Kota Padang dapat mengatasi resistensi warga. Namun demikian perlu disadari bahwa jika penerapan teori-teori komunikasi antarpribadi dilakukan secara tidak efektif, maka hal ini akan dapat menurunkan penghargaan masyarakat kepada pihak pemerintah sekaligus memperlambat proses negosiasi.

Proses komunikasi yang baik terbukti dapat menghilangkan sebagian besar gangguan komunikasi. Oleh karena itu maka pengalaman Pemko Padang dalam penyelesaian masalah 
pembebasan lahan jalan Padang Bypass ini dapat menjadi pembelajaran (lesson learnt) baik bagi proyek sejenis maupun proyek infrastruktur lainnya yang menghadapi kendala sosial.

\subsection{Saran}

Meskipun studi ini mengindikasikan langkah-langkah komunikasi yang ditempuh oleh aparat Pemerintah Kota Padang telah memperoleh hasil yang cukup positif dalam proses pembebasan lahan Padang-Bypass, namun masih diperlukan penelitian lebih lanjut tentang pada tingkatan struktur pemerintahan manakah komunikasi antarpribadi itu paling efektif dilakukan. Misalnya apakah komunikasi antarpribadi yang dilakukan oleh seorang camat akan sama efektifnya jika dilakukan oleh seorang walikota.

Selain itu karena penelitian ini hanya mengambil lokus penelitian di Kecamatan Kuranji, maka diperlukan juga penelitian lanjutan terhadap kecamatan-kecamatan bermasalah lain di sepanjang jalur Padang-ByPass.

\section{DAFTAR PUSTAKA}

Afrizal. (2006). Sosiologi Konflik Agraria: Protes-protes Agraria dalam Masyarakat Indonesia Kontemporer, Padang: Andalas University Press.

Afrizal. (2007). Jurnal Negara dan Konflik Agraria: Studi Kasus pada Komunitas Pusat Perkebunan Kelapa Sawit Berskala Besar di Sumatera Barat, Surabaya: FISIP Unair.

Afrizal. (2014). Metode Penelitian Kualitatif: Sebuah Upaya Mendukung Penggunaan Penelitian Kualitatif dalam Berbagai Disiplin Ilmu. Jakarta: RajaGrafindo Persada.

Budyatna, M, Ganiem, L.M. (2011). Teori Komunikasi Antarpribadi, Jakarta: Kencana Prenada Media.

Budyatna, M. (2015). Teori-teori Mengenai Komunikasi Antar-Pribadi, Jakarta: Prenadamedia.

Cangara, H. (2016). Pengantar Ilmu Komunikasi, Jakarta: Rajawali Pers.

Colombijn, F. (2006). Paco-paco (Kota) Padang, Yogyakarta: Ombak.

Dilla, S. (2012). Komunikasi Pembangunan Pendekatan Terpadu. Bandung: Simbiosa Rekatama Media.

Effendy, O.U. (2013). Ilmu Komunikasi Teori dan Praktek, Bandung: Remaja Rosdakarya.

Mulyana, D. (2005). Ilmu Komunikasi: Suatu Pengantar, Bandung: Remaja Rosdakarya.

Nurudin. (2016). Ilmu Komunikasi Ilmiah dan Populer, Jakarta: Rajawali Pers.

Suryanto. (2015). Pengantar Ilmu Komunikasi, Bandung: Pustaka Setia.

Tubbs, S.L., Moss, S. (2012). Human Communication Prinsip-prinsip Dasar, Bandung: Remaja Rosdakarya. 